\title{
The Need for a Coordinated Industrial Strategy to Boost Pakistani Exports: Lessons from Asia
}

\section{Azam Chaudhry* and Gul Andaman*}

\begin{abstract}
This paper focuses on a group of Asian countries that have successfully increased exports and found a common industrial strategy. Several key factors emerge from this study. First, countries that have managed to increase their exports focused on doing so in sectors in which they had expertise while slowly developing new export sectors at the same time. Second, high-growth Asian economies have developed their export sectors by making a significant move up the quality ladder and, in particular, moving away from low value-added to higher value-added exports. Third, there is no single economic policy that has worked across Asia; rather, successful exporters have used two or three policies in tandem to boost exports. Fourth, industrial policy has been coordinated with education and training policies to develop both the entrepreneurs and the workforce needed to produce high value-added exports. Finally, the only consistent factor that has an impact on high value-added export growth is domestic credit to the private sector. These results point to the urgent need for a coherent industrial strategy to boost Pakistan's exports (preferably before future trade agreements are signed, which could otherwise damage potential export sectors).
\end{abstract}

Keywords: Pakistan, East Asia, industrial policy, quality ladder.

JEL classification: F10, L50.

\section{Introduction}

There is little question that Pakistan is in the midst of a severe macroeconomic crisis, with the most immediate problem being a significant balance-of-payments constraint. Most analysts agree that the most sustainable way of resolving this problem would be to promote exports. Behind this simple statement, however, lie many complex questions.

Underlying our analysis of Asian countries that have successfully increased their exports is a series of interesting phenomena. First, such

\footnotetext{
*Professor and Dean, Department of Economics, Lahore School of Economics.

${ }^{* *}$ Research Assistant, Department of Economics, Lahore School of Economics.
} 
countries have followed a two-tier strategy: (i) increasing exports in those sectors where they already have expertise (textiles or electronics being obvious examples) and (ii) at the same time, slowly developing new export sectors while recognizing that it may take years (and sometimes decades) for these sectors to develop. Second, an analysis of export product varieties reveals an important common thread: Countries that have successfully increased their exports have not significantly expanded their product varieties. This means that these sectors have developed by making significant moves up the quality ladder and, in particular, by moving away from low value-added to higher value-added exports; in many cases, the same businesses have moved up the quality ladder. Third, there is no single economic policy that has worked across Asia; rather, successful exporters have used two or three policies in tandem to boost exports. So, there is no one-size-fits-all solution (contrary to what many analysts say about using exchange rate policies to boost exports). Finally, in a simple empirical analysis of which factors affect countries moving up the quality ladder in terms of higher value-added exports, the only consistent factor that has an impact is domestic credit to the private sector (and not the more commonly cited factors such as the exchange rate, the interest rate, and foreign direct investment [FDI]). What one can conclude from this analysis is that economic policies that promote exports are not related to exchange rate management or macroeconomic stabilization but rather to industrial policy. In other words, only a strong industrial policy can lead to export-led growth.

The structure of this paper is as follows: Section 2 looks at some of the existing literature on export diversification. In Section 3, we develop a simple methodology for examining how countries have transitioned from low value-added exports to a wider range of higher value-added exports. We then use this methodology to determine the historical pattern of export diversification in Asia. Section 4 reviews the specific policies followed by the Asian economies to boost exports. In Section 5, we discuss how these countries have chosen "winning sectors" and not "winners." Section 6 presents the results of a simple empirical analysis that looks at the factors that are correlated with moving from low valueadded to high value-added exports. Section 7 presents our conclusions.

\section{A Literature Review: Lessons From Other Asian Economies}

Export diversification has recently been at the center of the debate on how developing countries can improve their economic performance through trade. Broadly, the literature categorizes this discussion in terms 
of (i) how export diversification affects economic growth and (ii) the factors leading to export diversification. Ferdous (2011) focuses on the latter. Using the commonly employed Herfindahl index, ${ }^{1}$ she shows that East Asian exports became significantly diversified during the 1980s and 1990s. The main factors responsible for this were low tariff rates, exchange rate depreciation, and high trade intensity within the region. By the 2000s, most East Asian economies were specializing in the SITC 7+ category (transport equipment and machinery).

Kim (2012) and Yoo (2008) both explain the structure of export diversification in the Republic of Korea. They show that, in the 1960s, Korean exports comprised mainly SITC 6+8 category goods-products such as lowvalue manufacturing items (textiles, yarn, and other clothing accessories). In the 1980s, there was a significant shift toward the SITC 5+7 categories, which resulted in more value-added and diversified exports. These categories included transport equipment, office machinery, data processing equipment, and electrical machinery, etc. During this time, the Korean government adopted a range of policies such as duty-free imported raw materials, exchange rate devaluation, and other export promotion schemes, which, according to Mah (2010), also included "tax and financial incentives." As Kim (2012) points out, the country's top ten sources of export earnings changed from SITC $6+8$ to SITC $5+7$ over time.

Bebczuk and Berrettoni's (2006) empirical analysis of the export diversification path followed by a sample of Latin American and European countries shows that the Herfindahl index of export diversification initially decreased over the 1960s-1990s. They also find that countries with a higher ratio of manufactured exports to total exports are more likely to achieve product diversification in the future. Similarly, an economy with a higher ratio of agricultural exports to total exports will have less room for export diversification. The reason that Latin America and Europe (the latter having achieved export diversification earlier) were able to diversify their export portfolios is that their ratio of manufactured exports to total exports increased over time.

Amiti and Freund (2010) examine the "anatomy" of export growth in China. Their results show that China's export base increased by 500 percent within a span of 13 years (from 1992 to 2005). This pattern is not very different from that of other East Asian economies: a major shift in export product categories from SITC $0+6+8$ to SITC 7 . The authors also distinguish

${ }^{1}$ Where a value closer to 0 indicates more diversification and less specialization. 
between the extensive and intensive margins of export growth. The extensive margin reflects diversification in different types of product categories and exporting them across different regions of the world; the intensive margin explains diversification (or more types of products) within the same product category and more exports to the same destinations as before. The literature shows that economic growth is more strongly linked to the extensive margin of export growth: Amiti and Freund present evidence that China experienced growth through the extensive margin and was, therefore, able to improve its economic performance as well.

Agosin, Alvarez, \& Bravo-Ortega (2009) argue that factors such as higher levels of schooling and human capital, higher domestic credit as a percentage of GDP, and the absence of an "overvalued" exchange rate account for export diversification in many countries. Hobday (1996) uses Malaysia as a case study to explain how the process of innovation was initiated in East Asia and how this eventually led to a diversified export structure. Malaysian engineers who interacted with transnational companies such as Sony benefited from knowledge and technological spillovers. As employees learned more about the production of a particular high value-added product, they began to establish their own businesses or spinoffs, which then acted as raw material suppliers. The Malaysian government revamped university curricula to help engineers and other graduates learn to use modern technologies. It also attracted the Malaysian diaspora living and working abroad by offering them lucrative financial contracts. Such policies gave the country a competitive advantage and facilitated the production of higher value-added and more sophisticated products, which ultimately became its export base.

Some important lessons emerge from the discussion above. First, export-led growth in Asia has followed the extensive margin approach: instead of increasing exports in one particular category targeted at a small number of destinations, successful Asian economies have diversified their export base as well as destinations. Second, manufacturing exports matter more than agriculture-based exports for growth. So, while high-growth Asian economies have exported (and continue to export) agriculturebased goods, their long-term industrial strategies focused on manufactured exports. Third, these economies have relied intensively on technology spillovers from foreign manufacturers who had begun to produce within the country. As foreign companies set up manufacturing units in these countries, local engineers learned how to apply the technologies and production techniques being used and set up their own businesses producing these goods. This strategy was combined with 
focused university curricula and incentives for highly skilled overseastrained nationals to return home. This, in turn, created an environment conducive to foreign investment in these economies as well as a skilled group of individuals starting spinoff enterprises.

\section{How Successful Asian Economies Have Boosted Exports}

This section looks at the experience of Asian countries in increasing exports. What is obvious is that almost all the growth in this sample of economies has been export-led. What is not clear is how this occurred at a micro-level. In increasing exports, did the Asian economies just produce more of their existing low value-added products? Did they just start producing a larger variety of products across the quality scale? Or did they immediately recognize that they had to start replacing low value-added product varieties with higher value-added ones? Additionally, as they developed, did they try to "jump" to higher value-added exports in new sectors or did they start expanding relatively new sectors with low valueadded products at first? Finally, moving up the quality ladder, did firms start switching sectors at the expense of those already established?

Figure 1 traces the phases of export development for a sample of Asian countries. We have formulated a timeline that begins from 1965 and ends in 2010 and is divided into five phases. In the first two phases, economies gain export earnings mainly from low-value items such as agricultural products, tobacco and beverages, and other manufactured items such as textiles and furniture. In phase 3, economies take off to high valueadded items such as chemicals, machinery, and transport equipment. In phase 4, they continue to expand production in both types (low-value items as well as more advanced product categories). In phase 5, economies produce more high value-added items at the expense of the basic export items with which they had begun international trade in the first phase.

Figure 1: Phases of export development for a sample of Asian economies

\begin{tabular}{|c|c|c|c|c|c|c|c|c|}
\hline Indonesia & 1 & & & & & 3 & & 4 \\
\hline China & 1 & & & & 2 & 3 & 4 & \\
\hline Singapore & 1 & & & 3 & 4 & & & \\
\hline Pakistan & 1 & & & 2 & & & & 3 \\
\hline Malaysia & 1 & & 2 & 3 & 4 & & & \\
\hline Rep. of Korea & 1 & & & 3 & 4 & & & \\
\hline India & 1 & & & 2 & & & 3 & 4 \\
\hline \multirow[t]{2}{*}{ Thailand } & 1 & & & 2 & 3 & 4 & & \\
\hline & 1965 & 1975 & 1985 & 1990 & 1995 & 2000 & 2005 & 2010 \\
\hline
\end{tabular}


As the figure shows, most countries transitioned from the takeoff phase to the high value-added phase relatively quickly-unlike Pakistan, which is still stuck in the take-off phase of export development. More importantly, this shows that, since Pakistan is finally entering the early part of phase 3, it needs both (i) a coherent industrial policy that will induce significant investment in the higher value-added product categories in its existing exports (such as textiles) and (ii) a strategy for developing other sectors in which the country can start expanding exports. The lack of such an industrial policy is one of the glaring policy gaps in Pakistan today.

The second part of our analysis looks at how export categories and product varieties in each category have grown over time in a crosssection of Asian countries. The reason for this is simple. One idea is that export-led growth in a sector such as textiles means that a country starts by producing low value-added goods and then expands into higher value-added goods while, at the same time, retaining its low value-added exports. Another idea is that countries are either pushed out of producing low value-added goods (as costs increase) or that firms may decide to transition from low value-added to higher value-added as they grow (or some combination of both these ideas).

The figures in Appendix 1 give a cross-country breakdown of the number of product types in each export category as well as the value of exports in each category over time. This is done to show how product varieties and values have changed in each country over time. What is clear is that, after the initial export-led expansion, the number of product types in each category has stayed the same over time while the value of exports in each category has expanded significantly (which occurs as countries enter phase 3 of their export-led growth).

This is important for two reasons. First, it means that exports increased in each category primarily by moving up the value chain (the textiles sector, for instance, moved from the production of cloth to towels to garments to higher value-added garments). Second, unless one believes in a large-scale model of Schumpeter's creative destruction (which is not supported by the cross-country evidence), then manufacturers themselves have generally moved up the quality ladder in terms of what they are producing. In other words, export-led growth has to come from existing manufactures moving up the quality ladder. Merely producing larger quantities of the same type of export commodity (as Pakistan has been doing for many decades) simply does not work as a long-term growth strategy. 
A second observation concerns the growth in export categories and the types of products produced in each: Did countries that started with producing cloth then start producing large volumes of sophisticated electronics immediately? What the figures show is that successful countries initially increased their value-added in existing export categories and then started at the lower end of the quality scale in new products. Eventually, they began producing higher-quality exports in these categories, but without technology jumping. If one produces textiles and wants to start producing electronics, then one must start from the bottom of the scale in terms of electronics (no matter what the quality of textiles one exports) and moves one's way up.

This is important for a country such as Pakistan. Expertise in producing higher-value exports does not translate into expertise in producing higher value-added goods in other categories. Rather, any industrial policy that is developed will need to focus on producing simple low value-added goods in other categories for some time as expertise and skills in these areas develop.

Finally, these countries have, historically, retained production in sectors of comparative expertise. If they have exported textiles or electronics or agriculture-based commodities, they have continued to expand exports in those sectors while, at the same time, expanding exports in other sectors. The idea of reducing dependence on one sector (in the case of Pakistan's textiles sector) is not realistic. Reduced dependence is only observed in terms of other export categories catching up in the long term, but not by switching emphasis to preexisting export categories. Simply put, countries stick with what they are good at over time while developing expertise in other sectors in tandem.

\section{Choosing "Winning Sectors," not "Winners"}

The growth policies followed by our sample of Asian countries have all been based on developing a strong industrial policy. What makes the model interesting is that these countries have chosen "winners" in terms of "winning export sectors." Thus, Singapore chose to base its export-led growth in the electronics sector while China chose textiles and electronics (among others). While some countries may have chosen to focus incentives on a particular company or companies to lead their export promoting industrial strategy, some chose particular sectors and let competition determine the individual winners. 
Having determined their winning sectors, these countries then followed a long-term industrial policy in which the sectors started out as small exporters (producing low levels of value-added exports) and eventually expanded in terms of the number of products produced as well as value addition. Finally, these countries pursued trade policies that supported their chosen sectors by (i) incentivizing capital investment (through cheap credit and tariff policies that promoted capital imports), (ii) creating incentives for foreign multinationals to establish production sites locally (which aided in technology transfer), and (iii) pursuing trade policies that gave these sectors the space to develop.

These lessons are key for Pakistan: its lack of a coherent industrial policy has led to a relatively stagnant textiles sector and a set of policies that, instead of promoting new export categories (such as light engineering or machinery), have encouraged the influx of cheap foreign goods. This, in turn, is leading to the deterioration of sectors in which Pakistan has developed core competencies. It also means that free trade agreements (FTAs) with countries such as China and India may lead to a greater variety of goods becoming available at reasonable prices (potentially spurring technological upgrades because of increased competition), but could also limit the number of sectors on which Pakistan can focus for export expansion. In other words, FTAs in the absence of a coherent industrial policy could, potentially, trap Pakistan in a cycle of low value-added textile exports.

\section{Specific Industrial Policies in the Asian Context}

In this section, we look at a series of industrial policies pursued by Asian economies to boost exports. These range from exchange rate policies to tariff policies, the establishment of free trade zones (FTZs) and export zones, export insurance and credit policies, to policies attracting multinational enterprises (MNEs) and FDI. This menu of macroeconomic and industrial policies open to governments to promote exports is outlined in Appendices 2 and 3.

A few things stand out: First, there is no one policy that each country has adopted to boost exports; rather, each has adopted multiple policies simultaneously. China has relied heavily on FTZs and FTAs, the Republic of Korea and Indonesia have relied on export insurance and credit, and Singapore has focused on attracting FDI and MNEs to boost technological spillovers. It is also important to note that these countries have signed FTAs only with those countries that have significant markets for their export 
goods. So, as is the case with the China-Pakistan FTA, the prime beneficiary may potentially be Chinese exporters and not Pakistani exporters.

Second, there has been heavy emphasis on two major components of an export promotion strategy: the establishment of FTZs as well as export insurance, finance, and credit. Although Pakistan's experience with export credit has been mixed, very few effective incentives have been given to Pakistani exporters in terms of export insurance and particularly cheap financing. Third, Pakistan's strategy of developing industrial estates has not been followed extensively by other high-growth Asian economies.

A critical question in the context of export-boosting policies concerns exchange rates. Appendix 3 shows the various exchange rate policies followed by selected Asian economies over time and identifies phases 3 and 4, which represent periods of high-value export takeoff (see also Figure 1). In most cases, these economies have followed a system of either adjustable pegs or managed floats (within predetermined bands) as they were entering the takeoff period (phase 3 in Figure 1). Additionally, they have tended to pursue the same currency system throughout phase 3 and into phase 4 of their high-value export growth push.

What this discussion implies is that all the high-growth Asian economies chose a few industrial strategies and a managed exchange rate regime as they pushed toward high-value exports. For a country such as Pakistan that is just entering the stage of higher value-added exports, the message is simple: It is critical to develop (and effectively pursue) a few key aspects of an industrial strategy as well as developing a coherent exchange rate policy over time. This policy prescription is one that Pakistan has failed to follow.

\section{An Empirical Analysis of the Transition from Low to High Value- Added Exports}

Our empirical analysis examines factors that affect countries moving up the export ladder from low value-added exports to high value-added exports. In particular, we have looked at how (i) the exchange rate, (ii) the lending rate, (iii) the level of FDI, (iv) the level of domestic credit to the private sector, $(\mathrm{v})$ the percentage of the population with tertiary training, and (vi) the level of imports have affected the transition from low value-added exports to high value-added exports. Appendix 4 describes the variables used in the analysis. 
We perform two estimations. The first estimates a fixed-effects model in which the dependent variable represents high value-added exports as a proportion of total exports. The second estimates a logit model in which the dependent variable is the discrete variable we constructed in Section 3, showing the various phases of export development in our sample of Asian countries.

In the first set of results (see Appendix 5), we find that the only significant industrial policy variable determining the share of high valueadded exports is the amount of credit given to the private sector. This supports the idea that a critical component of export-led growth is a coherent and consistently followed industrial policy. What is also interesting is that there is no significant relationship between the exchange rate and the movement from low- to high-quality exports. There is, however, a significant relationship between imports and movement up the quality ladder. So, while imports may be the villain of the piece in terms of short-run stabilization and growth, as countries move up the quality ladder there is a significant increase in imports. ${ }^{2}$

The experience of the Asian economies is that these imports are primarily capital imports that have helped them upgrade the quality of their exports, and not consumer imports. In the case of Pakistan, this raises two important points. First, there is a strong case for incentives (in the context of a coherent industrial policy) to promote the import of capital that can help the country technically upgrade its exports. Second, the FTAs signed by Pakistan with China may turn out to be a key strategic error if the ultimate objective is to diversify the export base by starting to produce low value-added export goods in other categories.

The second set of results (also presented in Appendix 5) is based on the stages of export growth discussed in Section 3. What we find is extremely interesting. First, the level of tertiary training has a significant impact on countries moving from low to high value-added exports (whereas the level of secondary education is not significant in our results). Second, the exchange rate is positively related to moving from low to high value-added exports. In light of the discussion in Section 5, this means that countries that have successfully pursued export-led growth have carefully used the exchange rate (either through a system of moving pegs or carefully managed floats) to boost exports. Third, credit

\footnotetext{
${ }^{2}$ In a separate set of estimations not shown in this paper, we find that most of the increase in imports is due to an increase in intermediate imports, which supports the argument that imports can complement an industrial strategy.
} 
to the private sector and the interest rate are also very significant tools used by the Asian economies in moving from low to high value-added exports. Fourth, remittances are associated with export growth and imports tend to accompany an export-led growth strategy (though, as discussed above, these were primarily intermediate imports used in the manufacturing sector).

Again, these results have important implications for a country such as Pakistan that is slowly moving out of a low value-added export trap. First, there is an urgent need to coordinate vocational and technical training in Pakistan to support an industrial policy capable of generating high value-added exports. Second, this industrial policy has to make aggressive use of cheap and readily available credit to certain exportoriented (and potential high value-added export) sectors. Third, there has to be a coherent strategy that differentiates between the import of intermediate goods (which can be used in the manufacturing sector) and the wholesale import of all foreign goods (which could damage potential export sectors). This last point is extremely important as Pakistan is in the midst of pursuing FTAs without an industrial strategy that would help identify potential export sectors.

\section{Conclusion}

Unlike Pakistan, the Asian economies have pursued a set of coherent and consistent industrial policies to promote exports. Their strategy has been simple: a multi-tier set of policies that have helped core industries develop from low value-added to high value-added exporters while identifying secondary industries to develop over the medium term from simple exporters to high-quality exporters. These economies have not just let these sectors develop themselves; rather, they have identified "winning sectors" with the potential to start out slowly and expand into major export sectors. The strategies adopted have also been relatively simple: to provide cheap credit to these sectors while giving them incentive to improve their technology through imported capital or collaborations with foreign investors or MNEs. The economies in question also set tariffs at levels that allowed their chosen sectors to develop and, over time, relaxed these levels to allow competition.

In addition to these policies, the high-growth Asian economies have coordinated other policies with their long-term industrial strategies. So, universities were partnered with industrial sectors to develop a workforce that could not only work in the chosen industrial sectors but also learn from foreign technological advances to develop businesses of 
their own. Incentives were put in place to tempt nationals who had trained abroad in the chosen sectors to return and set up their own enterprises. The overall industrial policy was, therefore, beyond a set of policies to promote industrial output and exports. Rather, it was a coordinated strategy that combined macroeconomic policies, educational policies, financial sector policies, and focused sector-specific incentives.

This shows the weaknesses inherent in Pakistan's present policies. There is no coherent long-term industrial strategy that looks at how to move from low to high value-added textile exports. At the same time, there is no set of policies that identifies sectors in which Pakistanis could start developing basic exports and expanding these to high value-added exports over time. Interestingly, the country's strategy over the last few decades has been precisely the opposite: to let the textiles sector continue producing low value-added exports, have no coherent policies to provide cheap credit or improve technology, and sign FTAs with other economies that might have the effect of destroying other potential export sectors.

Simply put, what is not needed is a growth strategy or export strategy, but rather a medium- to long-term industrial strategy that (i) identifies winning sectors, (ii) provides them with incentives, (iii) builds capacity through education and training toward specific sectors, ${ }^{3}$ (iv) identifies Pakistanis with technical expertise abroad and creates incentives for them to return and expand certain sectors, (v) moves away from the idea of signing broad-ranging FTAs toward focused agreements that could lead to foreign technology transfer, and (vi) focuses on credit policies to promote technology upgrading in a few key sectors.

\footnotetext{
${ }^{3}$ A good starting point would be to focus Higher Education Commission scholarships, funding for Pakistani research, and technical and vocational training toward the pre-identified sectors.
} 


\section{References}

Agosin, M. R., Alvarez, R., \& Bravo-Ortega, C. (2009). Determinants of export diversification around the world: 1962-2000 (Working Paper No. 309). Santiago: Universidad de Chile.

Amiti, M., \& Freund, C. (2010). The anatomy of China's export growth. In R. C. Feenstra \& S.-J. Wei (Eds.), China's growing role in world trade (pp. 35-56). Chicago, IL: University of Chicago Press.

Anwar, S., \& Sun, S. (2011). Financial development, foreign investment and economic growth in Malaysia. Journal of Asian Economics, 22(4), 335-342.

Bebczuk, A. R. N., \& Berrettoni, N. D. (2006). Explaining export diversification: An empirical analysis (Working Paper No. 65). Buenos Aires: Universidad Nacional de La Plata.

Bown, C. P., \& Tovar, P. (2011). Trade liberalization, antidumping, and safeguards: Evidence from India's tariff reform. Journal of Development Economics, 96(1), 115-125.

Felipe, J., Kumar, U., \& Abdon, A. (2013). Exports, capabilities, and industrial policy in India. Journal of Comparative Economics, 41(3), 939-956.

Ferdous, F. B. (2011). Pattern and determinants of export diversification in East Asian economies. International Proceedings of Economics Development and Research, 5, 156-160.

Gumilang, H., Mukhopadhyay, K., \& Thomassin, P. J. (2011). Economic and environmental impacts of trade liberalization: The case of Indonesia. Economic Modelling, 28(3), 1030-1041.

Heo, Y. (2001). Development strategy in Korea reexamined: An interventionist perspective. The Social Science Journal, 38(2), 217-231.

Hernández, L., \& Montiel, P. (2001). Post-crisis exchange rate policy in five East Asian countries: Filling in the "hollow middle"? (Working Paper No. 01/170). Washington, DC: International Monetary Fund.

Hobday, M. (1996). Innovation in South-East Asia: Lessons for Europe? Management Decision, 34(9), 71-81. 
James, W. E., \& Ramstetter, E. D. (2008). Trade, foreign firms and economic policy in Indonesian and Thai manufacturing. Journal of Asian Economics, 19(5-6), 413-424.

Johansson, H., \& Nilsson, L. (1997). Export processing zones as catalysts. World Development, 25(12), 2115-2128.

Kim, D. (2012, March). Export diversification: Lessons from Korean experience. Paper presented at the International Conference on Chilean-Asian Economic Relations: Lessons for Latin America, Santiago, Chile.

Mah, J. S. (2010, October). Export promotion policies, export composition and economic development of Korea. Paper presented at the Law and Development Institute Inaugural Conference, Sydney, Australia.

Rajan, R. S. (2011). Management of exchange rate regimes in emerging Asia (Working Paper No. 322). Tokyo: Asian Bank Development Institute.

Shepherd, B., \& Wilson, J. S. (2009). Trade facilitation in ASEAN member countries: Measuring progress and assessing priorities. Journal of Asian Economics, 20(4), 367-383.

Talib, A. L. (2004). Pegging the Ringgit against the US dollar: An evaluation. Journal of the Department of Statistics, Malaysia, 1, 13-26.

Wang, J.-H. (2007). From technological catch-up to innovation-based economic growth: South Korea and Taiwan compared. Journal of Development Studies, 43(6), 1084-1104.

Yoo, J. (2008). How Korea's rapid export expansion began in the 1960s: The role of foreign exchange rate (Working Paper No. 08-18). Seoul: KDI School of Public Policy and Management. 


\section{Appendix 1}

Asian exports by product category and value added

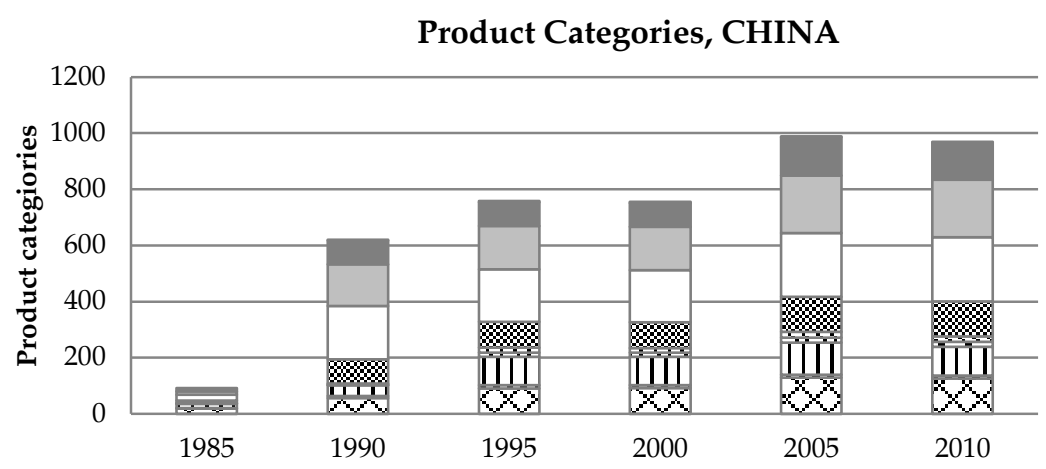

- SITC 9+ - SITC 8+ $\square$ SITC 7+ $\square$ SITC 6+ هSTC 5+ बSITC 4+ $\square$ SITC 3+ mSITC $2+$ $\triangle \mathrm{SITC} 1+$ 囚 SITC 0+

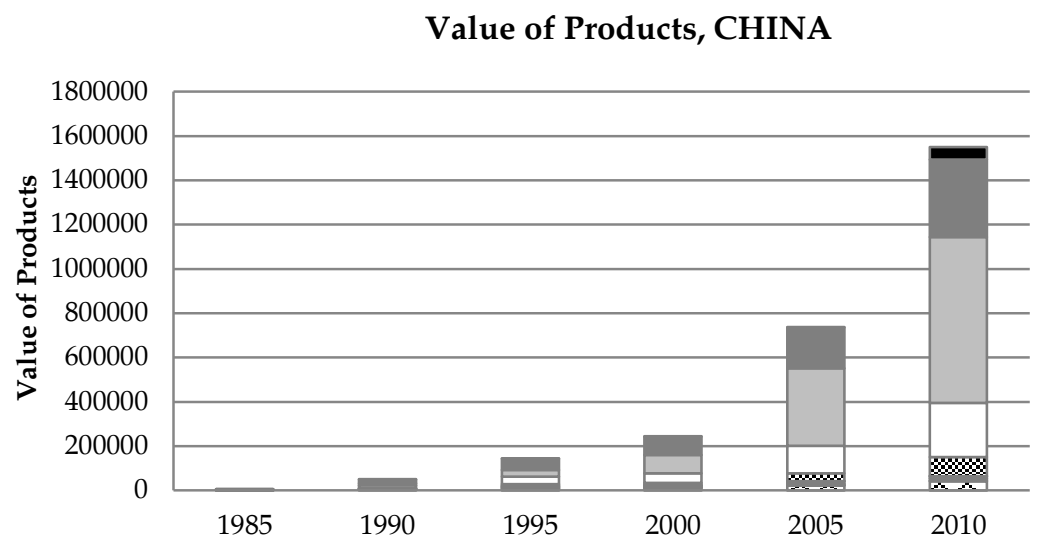

aSITC 9+

-SITC 8+

$\square$ SITC 7+

$\square$ SITC $6+$

खSITC $5+$

$\checkmark$ SITC 4+

๑SITC $3+$

DSITC 2+

$\triangle$ SITC $1+$

囚 SITC 0+

Product Categories, INDIA

- SITC 9+

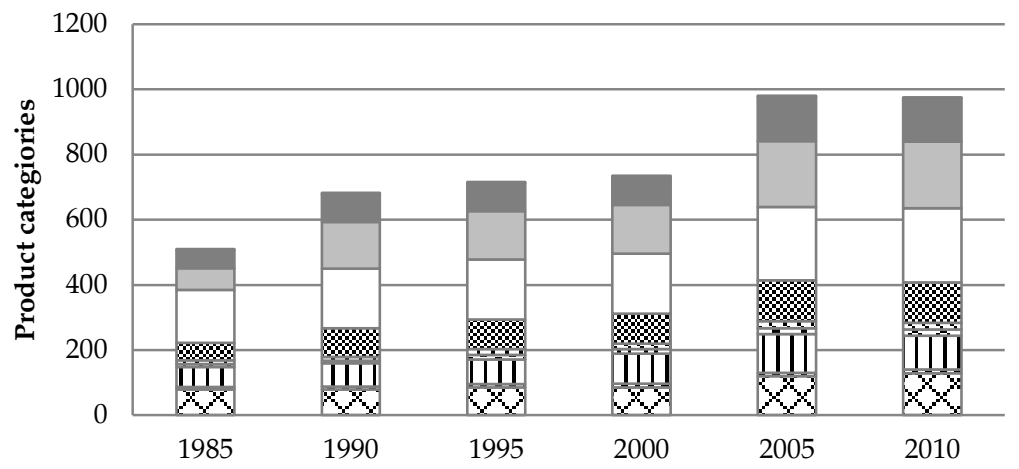

- SITC 8+

$\square$ SITC 7+

$\square$ SITC 6+

冈SITC $5+$

$\checkmark$ SITC $4+$

$\square$ SITC $3+$

๓SITC 2+

$\triangle$ SITC $1+$

囚SITC 0+ 


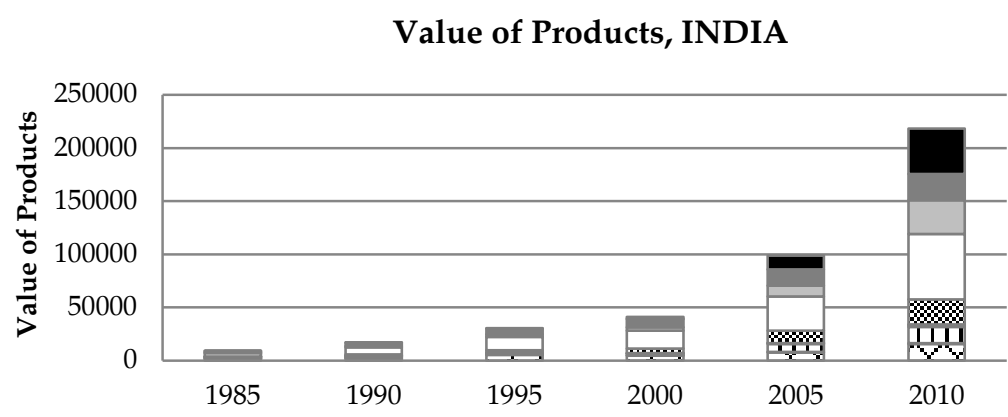

- SITC 9+ SITC 8+ $\square$ SITC 7+ $\square$ SITC 6+ 冈SITC 5+ बSITC $4+$ $\nabla$ SITC $3+$ ๑SITC 2+ $\triangle \operatorname{SITC} 1+$ $\triangle \mathrm{SITC} 0+$

Product Categories, INDONESIA

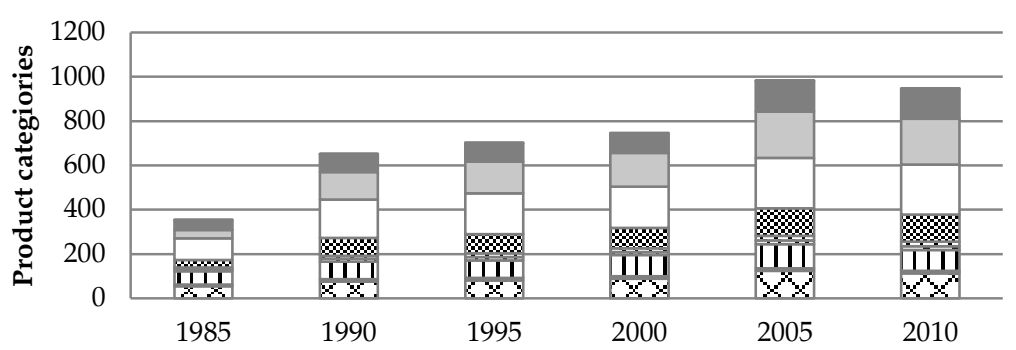

- SITC 9+ SITC 8+ $\square$ SITC 7+ $\square$ SITC 6+ 冈SITC $5+$ $\triangle$ SITC $4+$ $\square$ SITC $3+$ DSITC $2+$ $\triangle$ SITC $1+$ $\triangle \mathrm{SITC} 0+$

Value of Products, INDONESIA

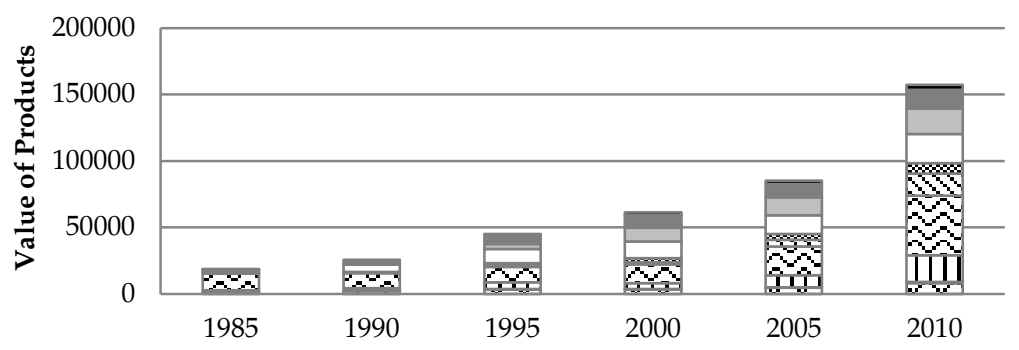

- SITC 9+ SITC 8+ $\square$ SITC 7+ $\square$ SITC 6+ ब SITC 5+ $\checkmark$ SITC $4+$ $\checkmark$ SITC $3+$ DSITC 2+ - SITC $1+$ $\triangle$ SITC $0+$

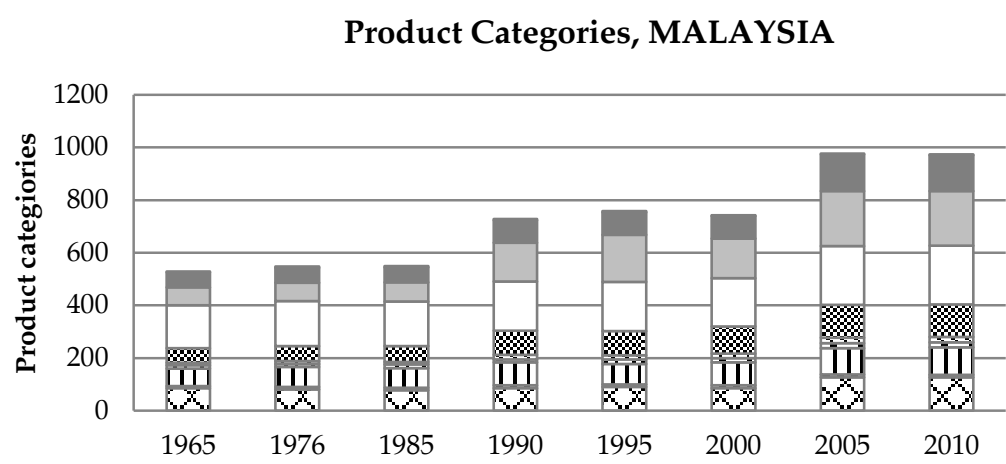

- SITC 9+ -SITC 8+ $\square$ SITC 7+ $\square$ SITC 6+ 冈SITC 5+ هSITC 4+ vSITC $3+$ 口SITC 2+ aSITC 1+ 口SITC $0+$ 


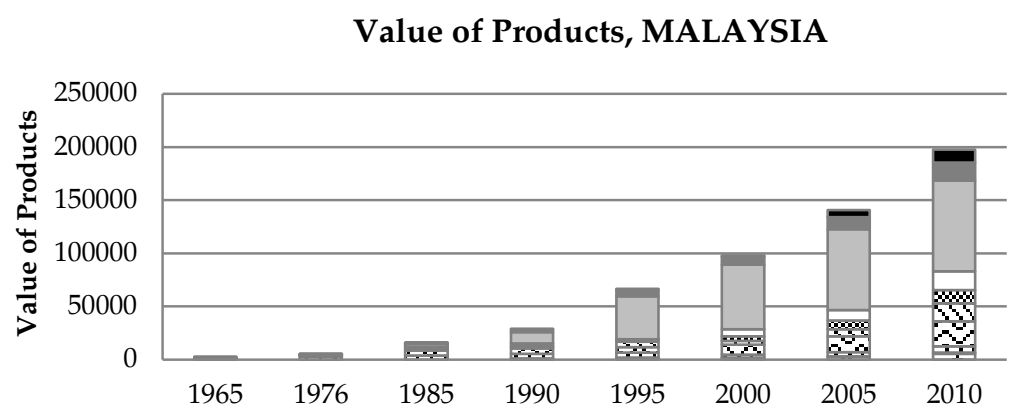

-SITC 9+

SITC 8+

$\square$ SITC 7+

$\square$ SITC 6+

冈SITC $5+$

$\triangle \operatorname{SITC} 4+$

$\square$ SITC $3+$

๓SITC $2+$

QSITC $1+$

$\triangle \mathrm{SITC} 0+$

Product Categories, SINGAPORE

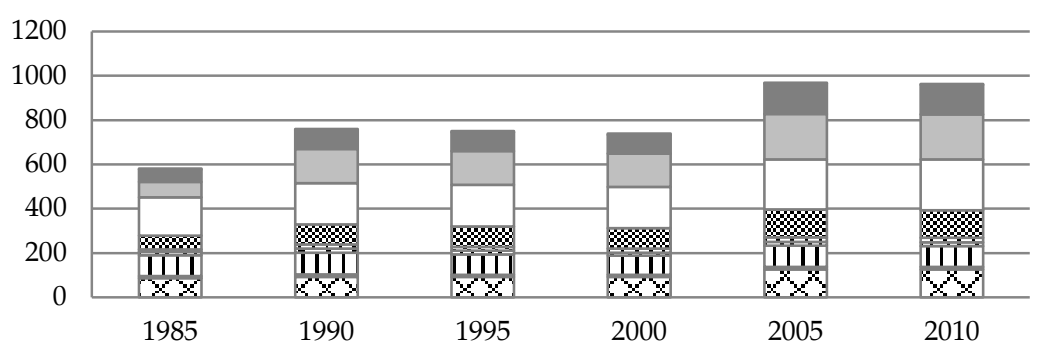

- SITC $9+$

SITC $8+$

$\square$ SITC 7+

$\square$ SITC 6+

圈 SITC 5+

बSITC $4+$

$\square$ SITC $3+$

DSITC 2+

$\triangle$ SITC $1+$

$\triangle \mathrm{SITC} 0+$

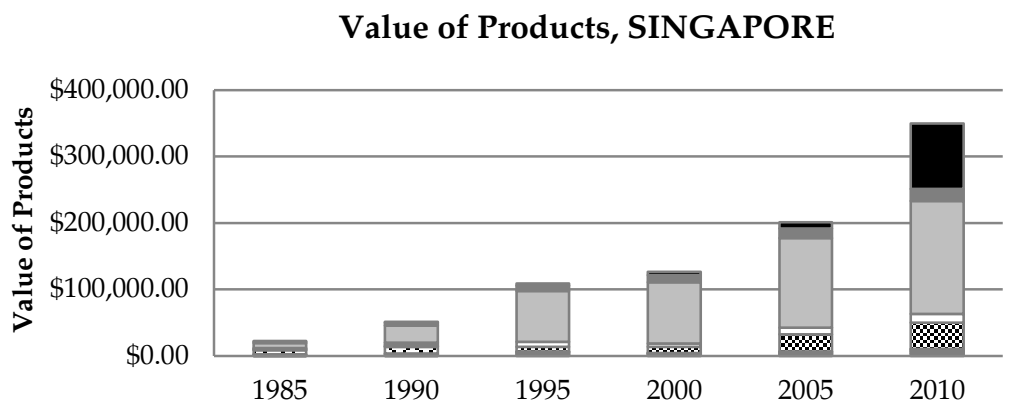

- SITC 9+

-SITC 8+

$\square$ SITC 7+

$\square$ SITC 6+

⿴囗十ㅇㄷㄴ 5+

ब SITC 4+

$\square$ SITC $3+$

口SITC 2+

$₫$ SITC 1+

$\checkmark$ SITC 0+

Product Categories, SOUTH KOREA

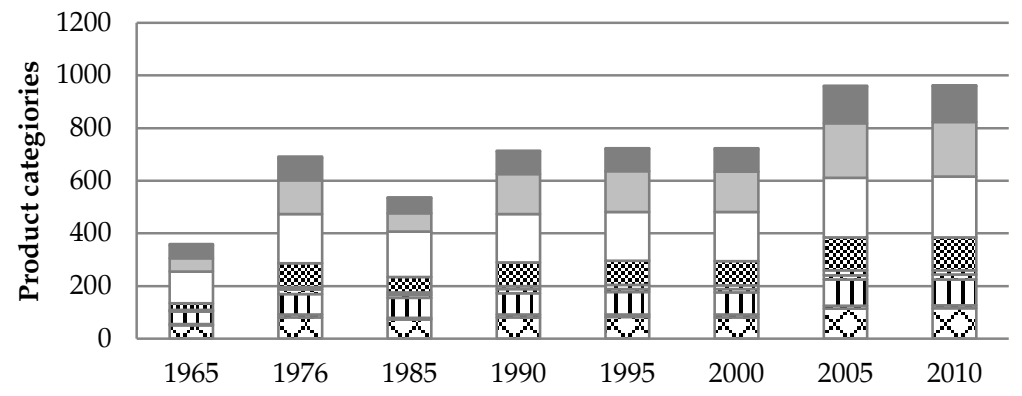

ロSITC 9+ SITC 8+ $\square$ SITC 7+ $\square$ SITC $6+$ SITC $5+$ ⿶SITC 4+ $\square$ SITC $3+$ ๓SITC 2+ ه SITC 1+ $\triangle$ SITC $0+$ 


\section{Export Earnings, SOUTH KOREA}

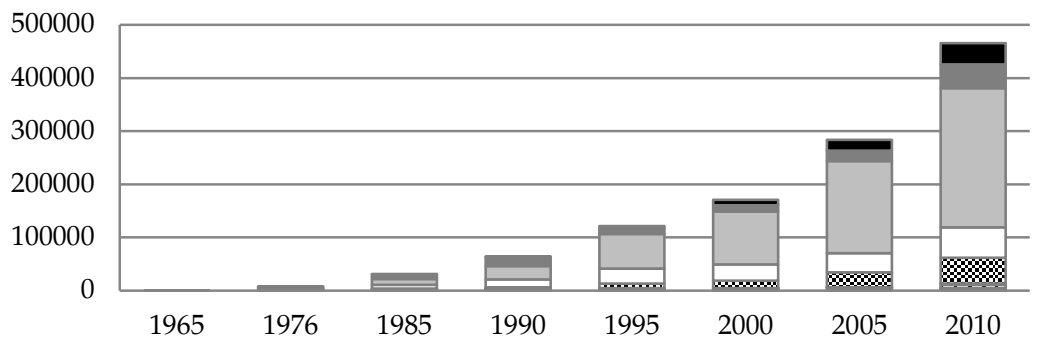

Product Categories, THAILAND

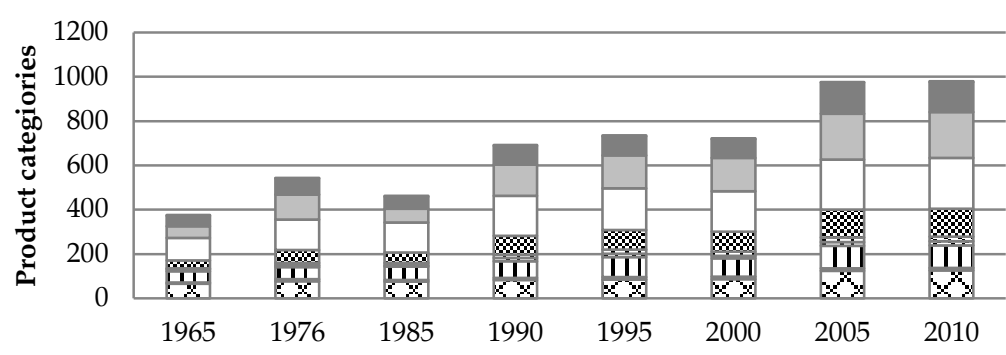

Value of Products, THAILAND

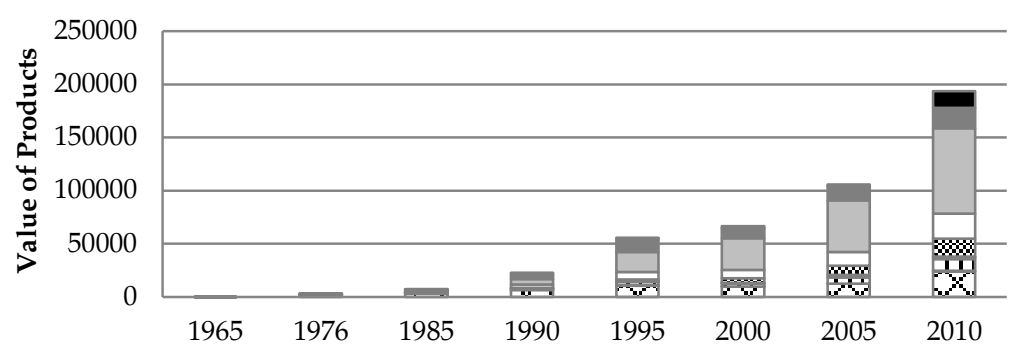

Product Categories, PAKISTAN

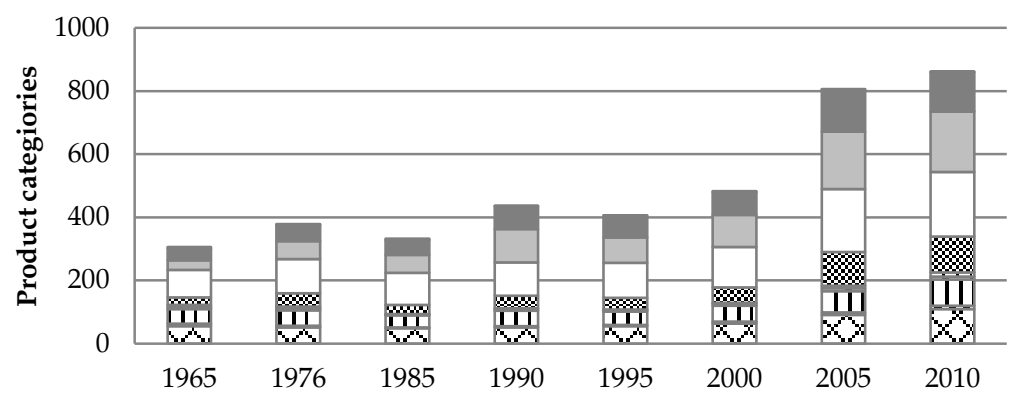

-SITC 9+ -SITC $8+$ $\square$ SITC 7+ 口SITC 6+ 四ITC 5+ $\triangle$ SITC 4+ $\square$ SITC $3+$ DSITC $2+$ $\triangle$ SITC $1+$ \SITC $0+$

$\square$ SITC 9+ - SITC 8+ 口SITC 7+ 口SITC 6+ 요은 5+ $\triangle$ SITC $4+$ $\square$ SITC $3+$ ISITC 2+ $\triangle \operatorname{SITC} 1+$ øSITC 0+

- SITC 9+ - SITC $8+$ $\square$ SITC 7+ 口SITC 6+ 이으 5+ जSITC 4+ $\square$ SITC $3+$ DSITC 2+ $\triangle$ SITC 1+ 口SITC $0+$

aSITC 9+ - SITC 8+ 口SITC 7+ 口SITC 6+ 圆SITC 5+ $\triangle$ SITC 4+ $\square$ SITC $3+$ DSITC 2+ $\triangle$ SITC $1+$ \SITC 0+ 


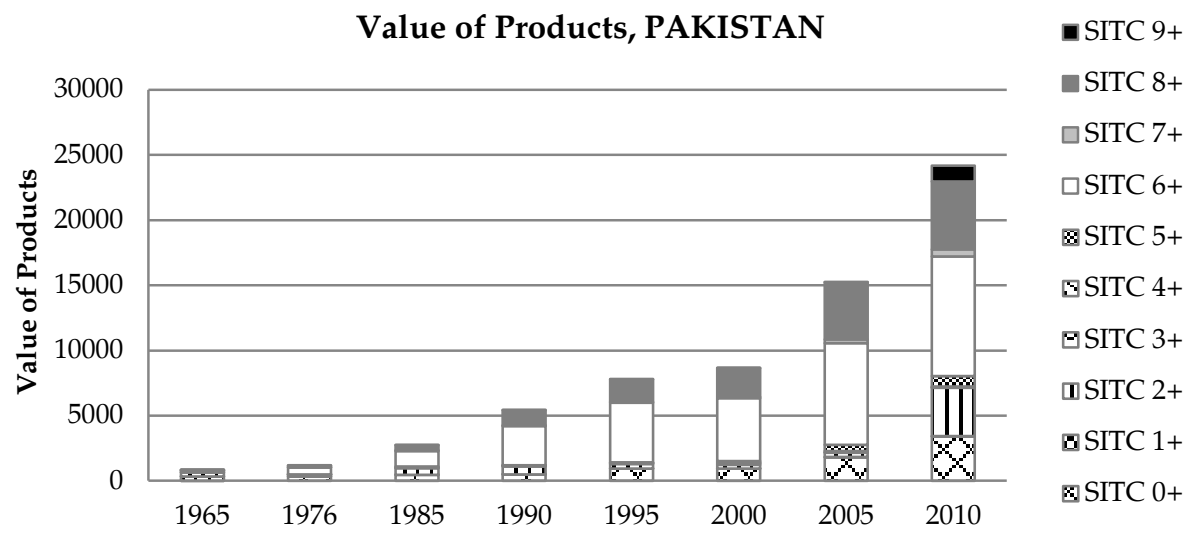




\section{Appendix 2}

\section{Components of Asian industrial strategy/export policy}

\begin{tabular}{|c|c|c|c|c|c|c|c|}
\hline & $\begin{array}{c}\text { Tariff } \\
\text { reduction }\end{array}$ & FTA/FTZ & EPZ & $\begin{array}{c}\text { Industrial } \\
\text { estates }\end{array}$ & $\begin{array}{c}\text { Export } \\
\text { insurance, } \\
\text { finance, } \\
\text { credits }\end{array}$ & $\begin{array}{c}\text { FDI, } \\
\text { MNEs, } \\
\text { TNCs }\end{array}$ & Other \\
\hline \multicolumn{8}{|l|}{ China } \\
\hline 1985-1990 & & & $x$ & & $x$ & & $x$ \\
\hline 1990-1995 & & $X$ & & & & $X$ & $X$ \\
\hline 1995-2000 & $x$ & $x$ & $x$ & & & & \\
\hline 2000-2005 & & $x$ & & & & & $X$ \\
\hline 2005-2010 & $X$ & $x$ & & & & & \\
\hline \multicolumn{8}{|c|}{ Republic of Korea } \\
\hline 1965-1970 & & & & $x$ & $x$ & & \\
\hline 1970-1975 & & $x$ & & & $x$ & $x$ & \\
\hline 1975-1980 & & & & & $x$ & & \\
\hline 1980-1985 & & & & & $x$ & & \\
\hline \multicolumn{8}{|l|}{ 1985-1990 } \\
\hline 1990-1995 & & & & & $x$ & $x$ & $x$ \\
\hline 1995-2000 & $X$ & & & & $x$ & & \\
\hline 2000-2005 & $x$ & $x$ & & & & & $\mathrm{x}$ \\
\hline 2005-2010 & & $x$ & & & & & $x$ \\
\hline \multicolumn{8}{|l|}{ Indonesia } \\
\hline 1985-1990 & $x$ & & & & $x$ & $x$ & $x$ \\
\hline 1990-1995 & $X$ & $x$ & & & $x$ & $X$ & $X$ \\
\hline 1995-2000 & $X$ & & & & & & \\
\hline 2000-2005 & $x$ & & & & & $x$ & $X$ \\
\hline 2005-2010 & $x$ & $x$ & $x$ & & & & \\
\hline \multicolumn{8}{|l|}{ Malaysia } \\
\hline \multicolumn{8}{|l|}{ 1965-1970 } \\
\hline 1970-1975 & & & $x$ & & $x$ & $x$ & $x$ \\
\hline 1975-1980 & & & & & $x$ & $X$ & \\
\hline 1980-1985 & & & & & & $\mathrm{X}$ & \\
\hline 1985-1990 & & & & & $x$ & & \\
\hline 1990-1995 & & $x$ & & & & & $x$ \\
\hline 1995-2000 & $x$ & & & & $x$ & & \\
\hline 2000-2005 & & $x$ & & & & & \\
\hline 2005-2010 & $x$ & $x$ & & & & & $x$ \\
\hline \multicolumn{8}{|l|}{ Thailand } \\
\hline 1970-1975 & $x$ & & & $x$ & & & \\
\hline 1975-1980 & & & & & & & \\
\hline
\end{tabular}




\begin{tabular}{|c|c|c|c|c|c|c|c|}
\hline & $\begin{array}{c}\text { Tariff } \\
\text { reduction }\end{array}$ & FTA/FTZ & EPZ & $\begin{array}{c}\text { Industrial } \\
\text { estates }\end{array}$ & $\begin{array}{c}\text { Export } \\
\text { insurance, } \\
\text { finance, } \\
\text { credits }\end{array}$ & $\begin{array}{c}\text { FDI, } \\
\text { MNEs, } \\
\text { TNCs }\end{array}$ & Other \\
\hline 1980-1985 & & & & & & $x$ & \\
\hline \multicolumn{8}{|l|}{ 1985-1990 } \\
\hline 1990-1995 & & $x$ & & & & & \\
\hline 1995-2000 & & & & & & $x$ & $x$ \\
\hline 2000-2005 & $x$ & $x$ & & & $x$ & & \\
\hline 2005-2010 & $x$ & $x$ & & & $x$ & & \\
\hline \multicolumn{8}{|l|}{ Singapore } \\
\hline 1985-1990 & $x$ & & & & & $x$ & \\
\hline 1990-1995 & $x$ & $x$ & & & & $x$ & \\
\hline $1995-2000$ & $x$ & & & & & $x$ & \\
\hline 2000-2005 & $x$ & $x$ & & & & $x$ & \\
\hline $2005-2010$ & $x$ & $x$ & & & & $x$ & $x$ \\
\hline \multicolumn{8}{|l|}{ India } \\
\hline $1985-1990$ & & & $x$ & & & & \\
\hline 1990-1995 & $x$ & $x$ & & & $x$ & $x$ & \\
\hline 1995-2000 & $x$ & & & & & & \\
\hline 2000-2005 & $x$ & $x$ & & & & & \\
\hline 2005-2010 & $x$ & & $x$ & & & & \\
\hline \multicolumn{8}{|l|}{ Pakistan } \\
\hline 1965-1970 & & & & & & & $x$ \\
\hline 1970-1975 & & & & & & & $x$ \\
\hline \multicolumn{8}{|l|}{ 1975-1980 } \\
\hline 1980-1985 & & & & & & & $x$ \\
\hline 1985-1990 & & & & & & & $x$ \\
\hline 1990-1995 & $x$ & & & & & $x$ & \\
\hline \multicolumn{8}{|l|}{ 1995-2000 } \\
\hline 2000-2005 & $x$ & & & & $x$ & $x$ & \\
\hline $2005-2010$ & $x$ & $x$ & & & & $x$ & \\
\hline
\end{tabular}

$\mathrm{EPZ}=$ export processing zone, $\mathrm{FDI}=$ foreign direct investment, $\mathrm{FTA}=$ free trade agreement, $\mathrm{FTZ}=$ free trade zone, $\mathrm{MNE}=$ multinational enterprise, $\mathrm{TNC}=$ transnational company. 
Appendix 3

\section{Asian exchange rate policies over time (matched with phases 3 and 4 of high-value export expansion):}

\section{China}

1985-1990 Controlled float, mainly pegged to US\$ (steep devaluation: 21.2\%). Foreign exchange swap market.

1990-1995 Devalued by 9.6\% (uniform swap rate or retention rate set).

1995-2000 Adjustable peg (swap rate abolished).

Phase 3

2000-2005 Crawling peg.

Phase 4

2005-2010 Crawling peg moving toward floating exchange rate.

Phase 4

\section{Republic of Korea}

1965-1970 A "unitary floating system" was established at a basic rate of W255.00/US\$.

1970-1975 The won was cut from W327.40/328.90 to W370.00/371.60 per US\$.

1975-1980 The support fund rate for the purchase of finished export goods for storage was lowered from W400 to W380 per US\$, and the rate for purchasing raw materials for exports was decreased from W450 to W430 per US\$ (IMF, 1979 , p. 250).

1980-1985 Devaluation: W484.00 to W580.00 per US\$.

The won's fixed link to the US\$ was abandoned and a controlled, floating effective rate was established. The exchange value of the effective rate was linked to the SDR in combination with a basket of the currencies of Korea's major trading partners.

1985-1990 The effective rate was replaced by a market average rate (MAR), which was

Phase 3 to be determined in the interbank market, based on a weighted average of rates for won/US\$ spot transactions of the previous day and was to float freely within margins of plus and minus $0.4 \%$ against the MAR.

The won-US\$ exchange rate in the interbank market was allowed to fluctuate within fixed margins of plus and minus $1.5 \%$ against the MAR of the previous day.

1990-1995 The won-US\$ exchange rate in the interbank market was allowed to

Phase 4 fluctuate within fixed margins of plus and minus $2.25 \%$ against the MAR of the previous day.

1995-2000 The won exchange rate was allowed to float freely, determined on the

Phase 4 basis of supply and demand.

2000-2005 Free float.

Phase 4

2005-2010 Korea was characterized as an independent floater.

Phase 4 


\section{Indonesia}

1985-1990 Managed floater (mainly pegged to US\$). The effective rate for the rupiah (Rp) was devalued by $31 \%$ in terms of the US\$. It was changed from Rp1,134 to Rp1,664 per US\$.

An export tax was implemented ranging from 5\% to $30 \%$.

The exchange rate system was revised. The effective rate, based on a managed float, would apply only to certain transactions undertaken at certain times of the day. An interbank free rate, which was determined between banks, would govern all other transactions.

1990-1995 Managed float.

Phase 3 Bank Indonesia announced daily buying and selling rates that were computed on the basis of a basket of weighted currencies with a spread of plus or minus Rp15.

Bank Indonesia announced buying and selling rates computed on the basis of a basket of weighted currencies with a spread of plus or minus Rp22.

1995-2000 Bank Indonesia, within a managed float system, determined the exchange Phase 3 rate. The system was based on a "conversion rate band" announced daily (for official transactions with foreign exchange banks, the government, and supranational institutions) and an "intervention band" (consisting of buying and selling rates that were computed on the basis of a basket of currencies). The spread of the intervention band was increased to Rp118 (5\%) from Rp66.

The spread of the intervention band was increased to Rp192, approximately $8 \%$, and then from 8 to $12 \%$.

The managed floating exchange regime was replaced by a free-floating exchange rate arrangement.

A foreign exchange subsidy for food was introduced, which led to the reclassification of the exchange rate system from unitary to dual.

2000-2005 Free floating of rupiah (softly pegged to US\$).

Phase 3

2005-2010 Recognized as a managed floater with no predetermined path for the Phase 4 exchange rate (basic policy goal: inflation targeting). 


\section{Malaysia}

1965-1970 The old pound sterling (GBP)-linked Malayan/Straits dollar was replaced by separate dollar currencies for Malaysia (M\$), Singapore, and Brunei. All three were freely interchangeable.

1970-1975 The M\$ was linked to the GBP at a fixed rate of M\$7.3469 per GBP. A new official rate was established at a rate of M\$2.81955 per US\$.

With the floating of the GBP and dismantling of the Sterling Area on 23 June 1972, Malaysia broke the M\$'s ties to the British unit and linked the currency to the US\$ with a fluctuation range for the effective rate (between M\$2.7561 and M\$2.8830 per US\$).

Following the US\$ devaluation in February 1973, the official rate of the M\$ was realigned to M\$2.5376 per US\$. The new fluctuation range for the effective range was defined as M\$2.4805-M\$2.5947 per US\$.

The Central Bank of Malaysia intervened in order to maintain relative stability in the value of the ringgit (RM) in relation to the basket of currencies (US, Japan, UK).

1975-1980 The controlled, floating effective rate for the ringgit was replaced; its external value was determined on the basis of its relationship with a weighted basket of currencies of Malaysia's major trading partners.

Rates for all other currencies were determined on the basis of the ringgitUS\$ rate and the US\$ rates for those currencies in markets abroad.

1980-1985 The recorded average exchange rate for every US\$ was RM2.63 during 1986-90, RM2.60 for 1991-95, or RM2.61 for 1986-95.

1985-1990 Following the IMF classification, Malaysia was considered pegged to a

Phase 3 composite basket of currencies.

1990-1995 Peg continued (stable exchange rate).

Phase 4

1995-2000 The exchange rate was no longer determined by demand and supply

Phase 4 following the crisis. The central bank announced that the exchange rate of the RM would be pegged against the US\$ at RM3.80 = US\$1.

2000-2005 RM3.8= US\$1 till 2003.

Phase 4 Although the exchange rate of the RM exhibited high correlation with the currencies of major trading partners, it was not completely fixed to specific currencies.

2005-2010 Recognized as a managed floater with no predetermined path for the Phase 4 exchange rate and no specific nominal anchor. 


\section{Thailand}

1965-1970 The original floating exchange rate regime was abolished. Thailand adopted a fixed exchange rate regime linked to the US\$ at a peg rate of B20.08 per US\$.

1970-1975 The devaluation of the US\$ led to the baht's devaluation.

The central bank introduced a $4.5 \%$ fluctuation range, which allowed the exchange rate to float within a limited range, revalued to B20.00 per US\$.

1975-1980 The baht's link to the US\$ was broken and an effective rate was established.

The external value of the baht was determined on the basis of a weighted basket of currencies of Thailand's major trading partners, including the US\$, West German mark, Swiss franc, and Japanese yen.

The baht was upgraded to B20.175/20.225 per US\$. The effective rate was controlled on a floating basis. The controlled floating rate was later devalued to B20.39/US\$.

Devaluation continued to B20.45/US\$.

1980-1985 Devaluation continued to B20.63/US\$.

The soaring US\$ increased the cost of imports while depressing the receipts of exports. Therefore, Thailand downgraded the baht by $1.08 \%$ to B21.00 per US\$.

The baht was devalued by $8.7 \%$ to B23.00 per US\$.

The baht underwent its biggest change in the currency's history: from B23.00 to B27.15 per US\$ (devaluation of $14.8 \%$ ).

The Exchange Equalization Fund announced that the basket of currencies would be revised to include the US\$, Japanese yen, West German mark, GBP, Malaysian ringgit, Hong Kong dollar, and Singapore dollar.

1985-1990 Baht revalued to B26.13/US\$.

Following a series of interventions by the central bank, the baht depreciated 2\% from B26.19 to B26.69 per US\$ in an attempt to assist exports and stop capital outflow. A "managed float" was used to control the currency.

Following the IMF classification, Thailand was considered pegged to a composite basket of currencies (25.69/US\$).

1990-1995 The Exchange Equalization Fund announced that the basket of currencies Phase 3 would be increased from 7 to 10 currencies. The additional currencies included the Brunei dollar, Indonesian rupiah, and Philippine peso. The exchange rate fluctuated between B25.255/US\$ to B25.09/US\$.

1995-2000 The exchange rate was devalued marginally to B25.19/US\$.

Phase 4 In 1997, the baht exchange rate was determined on the basis of supply and demand in the foreign exchange market and allowed to float freely (independently floating).

The authorities introduced a two-tier currency market created to separate exchange rates for investors who had bought baht in domestic versus overseas markets (which was later unified).

2000-2005 Independent floating exchange rates.

Phase 4

2005-2010 Recognized as a managed floater with no predetermined path for the 


\section{Singapore}

1985-1990 The Singapore dollar (S\$) was permitted to float according to supply and Phase 3 demand on the foreign exchange market, but would be monitored by the monetary authority against a trade-weighted basket of currencies.

1990-1995

Phase 4

1995-2000

Phase 4

The authorities used the exchange rate as an intermediate target, allowing the S\$ to fluctuate within an undisclosed band. They widened this target during the Asian crisis but did not publicly announce the width of the band.

2000-2005

Phase 4

2005-2010

Phase 4

Recognized as a managed floater with no predetermined path for the exchange rate.

The S\$ is managed against a basket of currencies of major trading partners (also known as the $\mathrm{S} \$$ nominal effective exchange rate or S\$NEER).

\section{India}

1985-1990 The Indian rupee (INR) was linked to a basket of currencies with the GBP and US\$ assigned the most weight.

The Reserve Bank of India (RBI) announced it would henceforth purchase the GBP at a revised notional rate of $£ 1=$ INR 14 , and the US $\$$ at US $\$ 1=$ INR 13 under the Foreign Currency Nonresident Accounts (FCNR) Scheme. A revised notional rate of $£ 1=$ INR15 was introduced and later devalued to $£ 1=$ INR16.

The RBI began to announce, on a daily basis, its buying and selling rates for the currencies of the member countries of the Asian Clearing Union.

It was announced that the Reserve Bank would henceforth purchase GBP under the FCNR Scheme at the revised notional rule of $£ 1=$ INR17 and the US\$ at US\$1 = INR12 (later revised to US\$1 = INR13.12).

By December 1989, ER $\rightarrow$ US\$1 = INR17.035.

1990-1995 The INR was devalued by $9.29 \%$ and then by $11.3 \%$. New exchange rate US\$1 = INR25.95.

In 1992, a dual rate system was created. The effective rate would govern only certain import payments, $40 \%$ of export and invisibles' receipts, and official grants and IMF transactions. All other dealings would come under an interbank free rate determined by supply and demand in the interbank market. In 1993, the rate system was unified at the interbank free rate and the INR was fully convertible. All foreign exchange transactions would be conducted by authorized dealers at market-determined rates. Authorized dealers would not be required to transfer to the RBI any portion of foreign exchange that was surrendered to them by exporters of goods and services. The rate listed since was the interbank free rate.

Shift toward market-determined ER.

INR depreciated to US\$1 = INR31.37.

1995-2000 Further depreciated to INR35.18.

2000-2005 INR determined by demand and supply, averaging between INR44 and

Phase 3 48/US\$.

In line with the exchange rate policy, the INR moved in line with economic fundamentals in the post-reform period (mid-1990s). 
2005-2010 Recognized as a managed floater with no predetermined path for the exchange Phase 4 rate and no specific nominal anchor (averaged between INR40 and 45/US\$).

\section{Pakistan}

1965-1970 The Pakistan rupee (Pre) was pegged to the US\$ at US\$1 = PRs4.76 (analysts thought the rupee was overvalued).

1970-1975 The exchange rate was maintained at US\$1 = PRs 4.76 till 1971. In 1972, the PRe was devalued by $56.7 \%$ in terms of gold to a new, unified official rate of PRs11.00 per US\$. A 4.5\% fluctuation range for the currency was also introduced. At the same time, the entire Export Bonus Voucher scheme with its complex of accessory rates was abolished.

In February 1973, the US\$ was devalued by $10 \%$, which led to the subsequent revaluation of the PRe by $10 \%$ to PRs 9.90 per US\$. It remained fixed at this level until the decision to adopt a managed float in 1982.

1975-1980

1980-1985 During the early 1980s, the real effective exchange rate appreciated substantially due to the appreciation of the US\$ against major currencies and higher domestic inflation compared to trading partners. Keeping in view this sharp appreciation, Pakistan adopted a managed floating exchange rate system on 8 January 1982.

A controlled, floating effective rate for the PRe, initially at PRs10.10 per US\$, was established in relation to a trade-weighted basket of currencies. By 1984, the PRe had depreciated to PRs15.36/US\$.

1985-1990 By 1989, it had depreciated to PRs21.42/US\$.

1990-1995 Nominal devaluation continued in the 1990s, from PRs24.72/US\$ to PRs34.28/US\$ by 1995.

With the transformation of the economy from a semi-closed to a more open or market-oriented economy at the beginning of the 1990s, the exchange rate was devalued far more in nominal terms, which was just offset by the higher level of inflation in Pakistan compared to its trading partners.

1995-2000 The State Bank of Pakistan (SBP) introduced a numbers of measures, including the implementation of a two-tier exchange rate system in July 1998 to steer the economy away from crisis.

The exchange rate arrangement was reclassified from "other conventional fixed peg arrangement" to "managed floating with no preannounced path for the exchange rate." The exchange rate was determined in the interbank foreign exchange market as a weighted average of a free interbank rate and the official exchange rate (December 1998).

The weights of the floating interbank rate and official exchange rate in the composite exchange rate were changed to $95 \%$ and $5 \%$, respectively.

The multiple exchange system was unified (May 1999). The PRe was floated, only to be informally controlled by the SBP within a narrow range of PRs52.10-52.30 rupees to the US\$.

The PRe exchange rate was de facto pegged to the US\$. The exchange rate arrangement was reclassified as a "conventional fixed pegged arrangement" from the category "managed floating with no preannounced path for the exchange rate" (by June 1999). 
2000-2005 In July 2000, the SBP moved to a floating exchange rate regime. Initially, the PRe/US\$ parity witnessed a sharp nominal depreciation of $18.5 \%$ during FY2001, which showed a market correction of the cumulative overvaluation that took place in FY1999/2000. Under the new exchange rate regime, monetary instruments were used as a nominal anchor to curb the anticipated high volatility of the exchange rate. This, coupled with the buildup of forex reserves, led to stability in the nominal exchange rate after the sharp depreciation in FY2001.

The SBP avoided an abrupt exchange rate appreciation in 2001-04 by purchasing US $\$ 8.2$ billion in October 2001-March 2004 to preserve exports competitiveness.

2005-2010 Recognized as a managed floater with no predetermined path for the Phase 3 exchange rate.

The PRe depreciated significantly during this period. 


\section{Appendix 4}

\section{Description of variables used in estimations}

\begin{tabular}{ll}
\hline Variable & \multicolumn{1}{c}{ Description } \\
\hline $\begin{array}{l}\text { Percentage of high value-added } \\
\text { export categories }\end{array}$ & Exports in SITC (5+6+7+8) codes/total exports \\
$\begin{array}{l}\text { Percentage of secondary } \\
\text { schooling attained }\end{array}$ & $\begin{array}{l}\text { Secondary schooling attained (not necessarily } \\
\text { completed) over time among total population }\end{array}$ \\
$\begin{array}{l}\text { Percentage of tertiary schooling } \\
\text { attained }\end{array}$ & $\begin{array}{l}\text { Tertiary schooling attained (not necessarily } \\
\text { completed) over time among total population }\end{array}$ \\
Exchange rates & Exchange rate (period average) \\
Domestic credit to the private & Domestic credit to the private sector as percentage of \\
sector & GDP \\
Foreign direct investment & Foreign direct investment, net inflows (\% of GDP) \\
Personal remittances & Personal remittances, received (\% of GDP) \\
Lending interest rate & Lending interest rate (\%) to private sector \\
Trade openness & Openness defined as (exports + imports/GDP) at \\
& constant prices \\
Imports & Total imports as \% of GDP \\
Intermediate imports & Intermediate imports + capital imports/total imports \\
\hline
\end{tabular}




\section{Appendix 5}

\section{Regression results}

\section{Table A5.1: Fixed-effects model of high-value export growth in a sample of Asian economies}

\begin{tabular}{|c|c|c|}
\hline Variable name & Coefficient & Standard error \\
\hline Secondary level attainment in total population & 0.0319782 & 0.1810342 \\
\hline Tertiary level attainment in total population & $-0.9778628^{* * *}$ & 0.4181360 \\
\hline Exchange rate & 0.0014843 & 0.0014999 \\
\hline Domestic credit to private sector as percentage of GDP & $0.2273099 * *$ & 0.1069705 \\
\hline Foreign direct investment, net inflows ( $\%$ of GDP) & 0.8852764 & 0.7237738 \\
\hline Lending interest rate & 0.2396041 & 0.7365707 \\
\hline Total imports as $\%$ of GDP & $0.5230164^{* * *}$ & 0.2054949 \\
\hline \multicolumn{3}{|c|}{$\begin{array}{l}\text { Number of observations }=44 \\
\qquad \mathrm{R}^{2}=0.5374\end{array}$} \\
\hline \multicolumn{3}{|c|}{$\begin{array}{l}\text { Note: Dependent variable }=\text { total amount of high value-added exports as a proportion of } \\
\text { total exports. }{ }^{* *} \text { Significant at } 1 \%,{ }^{* *} \text { significant at } 5 \%,{ }^{*} \text { significant at } 10 \% . \\
\text { Table A5.2: Ordered logit model of stages of export growth between } \\
1965 \text { and } 2010 \text { in a sample of Asian economies }\end{array}$} \\
\hline Variable name & Coefficient & Standard error \\
\hline Secondary level attainment in total population & -0.0121959 & 0.0294395 \\
\hline Tertiary level attainment in total population & $0.1006378^{*}$ & 0.0578499 \\
\hline Exchange rate & $0.00064700^{* *}$ & 0.0003160 \\
\hline Domestic credit to private sector as percentage of GDP & $0.0326102^{*}$ & 0.0172840 \\
\hline Foreign direct investment, net inflows (\% of GDP) & 0.2079195 & 0.2914196 \\
\hline Lending interest rate & $-0.3564100^{* * *}$ & 0.1321924 \\
\hline Personal remittances received (as \% of GDP) & $1.0205500^{* *}$ & 0.4718146 \\
\hline Total imports as \% of GDP & $0.3622970^{* *}$ & 0.0177036 \\
\hline \multicolumn{3}{|c|}{$\begin{array}{c}\text { Number of observations }=38 \\
\text { Pseudo- } R^{2}=0.4513\end{array}$} \\
\hline
\end{tabular}

Note: Dependent variable is measured on a scale from 1 to 4 where $1=$ the country is exporting low value-added goods and $4=$ the country is exporting high value-added goods. ${ }^{* * *}=$ Significant at $1 \%,{ }^{* *}=$ significant at $5 \%,{ }^{*}=$ significant at $10 \%$. 